\title{
Atrofik kaynamamada kullanılan kemik greftleri
}

\author{
Bone grafts in the treatment of atrophic nonunion
}

\author{
Merter Yalçınkaya \\ Medicana International İstanbul Hastanesi, Ortopedi ve Travmatoloji Kliniği, İstanbul
}

Tüm kırık kaynamama durumları içerisinde atrofik kaynamama tedavi etmesi en zor, sıklıkla birden fazla cerrahi girişim gerektiren ve iyileşme süreci en uzun olan olguları içerir. Atrofik kaynamamayı tedavi etmek isteyen bir ortopedistin, vaskülaritenin oldukça kötü ve hücresel iyileşme mekanizmalarının oldukça zayıf olduğu bir klinik tablo ile uğraştığını aklından çıkartmaması gerekmektedir. Biyolojik stimülasyonun sağlanmasında gerekli olan kaynamama sahasının greftlenmesi, tedavinin en önemli basamaklarından biridir. Tercih edilecek greftin biyolojik potansiyeli yüksek, hücresel döngüsünün hızlı ve osteojenik kapasitesinin fazla olması, tedaviyi olumlu yönde etkiler. Bu nedenlerden dolayı, otojen greftler greftleme materyalleri içerisinde altın standart olarak kabul edilmektedir. Otojen greftlerin neden olduğu donör sahası morbiditesi, temin edilebilen greft miktarının sınırlı olması ve iyileştirme potansiyellerinde kişisel farklılıklar, kırık iyileşmesini kolaylaştıracak sentetik biyolojik greftlerin araştırılmasına neden olmuştur. Biyomedikal araştırmaların ürünü olan allojen greftler, sentetik greftler, biyoseramikler ve heterojen greftlerin osteokondüktif ve osteoindüktif özellikleri birbirinden farklıdır ve biyolojik özellikleri atrofik kaynamama olgularında kullanılma durumlarını belirleyen en önemli kriterdir. Atrofik kaynamama tedavisinde başarılı sonuç elde etmenin temelinde yer aldığını düşündüğümüz kemik greftleri ve biyolojik özellikleri, özet olarak, bu derlemede yer almaktadır.

Anahtar sözcükler: kaynamama; atrofik; greft; otojen; allojen; osteoindüktif; osteokondüktif

\begin{abstract}
Atrophic nonunions are the most challenging cases to treat among all nonunion situations, generally requiring multiple operations and long periods of recovery. It is of paramount importance for an orthopedic surgeon treating an atrophic nonunion case that he/she is in fact dealing with a clinical status in which vascularization of bone is very poor and cellular healing mechanisms are quite weak or absent. One of the most important steps of treatment in such cases is the grafting of the atrophic nonunion site, which is necessary for achieving biological stimulation. Preferring a graft that has a potent biological feature, rapid cellular cycle and a superior osteogenic capacity affects the nonunion treatment positively. For these reasons autogenous grafts are accepted as gold standard among all graft options. Donor site morbiditiy, limited availability and individual differences in the healing potentials of autogenous bone grafts have led to the search for synthetic biologic grafts as potential methods to enhance fracture healing. The osteoconductive and osteoinductive properties of allogeneic grafts, synthetic grafts, bioceramics, and heterogeneous grafts which are all products of biomedical researches are different from each other, and these unique biological properties are the most important criteria that determine the need and the type of the non-autogenous grafts to use in an atrophic nonunion case. Bone grafts and their biologic features, which we believe are the basis for a successful outcome in atrophic nonunion treatment, are summarized in this review.
\end{abstract}

Key words: nonunion; atrophic; graft; autogenous; allogenous; osteoinductive; osteoconductive

\section{ATROFIK KAYNAMAMA}

Atrofik kaynamama durumlarında tercih edilmesi gereken tedavi yöntemlerine ve greftleme türüne karar vermek için, her kaynamama tipinde olduğu gibi, öncelikle atrofik kaynamamanın tanımının ve nedenlerinin çok iyi anlaşılması gerekir. Atrofik (diğer adıyla avasküler) kaynamama tanımlaması kırık sahasında biyolojik reaksiyon kapasitesinin olmadığı durumu ifade eder. ${ }^{[1,2]}$ Bu tür kaynamamalarla ilgili yapılmış sintigrafi çalışmalarında, kırık fragmanlarının uç kısımlarında kanlanma miktarının zayıf olduğu gösterilmiştir. ${ }^{[1,2]}$ Bu iki cümlenin iyi anlaşılması açısından tekrarlamak gerekirse; atrofik kaynamamayı tedavi etmek isteyen bir ortopedistin vaskülaritenin oldukça

- İletişim adresi: Doç. Dr. Merter Yalçınkaya, Medicana International İstanbul Hastanesi, Ortopedi ve Travmatoloji Kliniği, Beylikdüzü Cad. No: 3 , 34520, Beylikdüzü, İstanbul Tel: 0212 - 8677500 e-posta: merter_99@hotmail.com

- Geliș tarihi: 1 Kasım $2017 \quad$ Kabul tarihi: 1 Kasım 2017 
kötü ve hücresel iyileşme mekanizmalarının oldukça zayıf olduğu bir klinik tablo ile uğraştığını aklından çıkartmaması gerekmektedir.

Atrofik kaynamamanın dört farklı alt tipi bulunmaktadır. ${ }^{[1,2]}$ Torsiyon kama kaynamama, kanlanma miktarının azaldığı ya da tamamen ortadan kalktığı kama şeklinde bir kemik parçanın bulunduğu klinik tabloyu ifade eder. Bu kemik parçanın bir tarafı ana kemiğe kaynamışken diğer tarafı kaynamamıştır. En tipik örneği, plak ve vida ile fiksasyonun sağlanmaya çalışıldığı kama şeklinde kemik parçası içeren tibia kırı̆̆ıdır. Parçalı kaynamama, nekrotik özellikte olan bir ya da daha fazla kırık parçasının eşlik ettiği kaynamamadır. Radyografik olarak kallus oluşumunun herhangi bir bulgusuna rastlanılmadığı parçalı kaynamama, tipik olarak akut bir kırı̆ın stabilizasyonunda kullanılan plakların kırılması sonucu karşımıza çıkar. Defektli kaynamama kemiğin diyafizer bölgesindeki bir parçanın kaybı ile karakterizedir. Fragman uçları canlıı̆̆ını korumasına rağmen defekt arasında kaynamanın gelişmesi imkânsız hale gelmiştir. Zamanla canlı olan fragman uçları atrofik hale gelir. Bu kaynamama tipi, açık kırıklarda, sekestrektomi uygulanmış osteomiyelit olgularında ve tümör rezeksiyonu sonrasında karşımıza çıkar. Zamanında ve uygun yöntemler ile tedavisi planlanmamış kaynamama süreci, ara kemik parçaların olmadığı ve bu parçaların yerini osteojenik potansiyele sahip olmayan skar dokusunun doldurduğu atrofik kaynamama ile sonuçlanır.

Anlatıldığı üzere, atrofik kaynamama tiplerinde ya kanlanmanın az olduğu nekrotik kemik parçaları ya da kemik defekti bulunmaktadır. Tedavinin aşaması olarak nekrotik kemik parçalarının ortamdan uzaklaştırılması veya kanlanma elde edilinceye kadar yapılacak bir kemik debridmanı ya yeni bir kemik defekti sahası ile sonuçlanır ya da mevcut kemik defektinin boyutunu arttırır.

Atrofik kaynamamanın tedavisinde biyomekanik stabilite ve biyolojik stimülasyon mutlaka sağlanmalıdır. ${ }^{[2,3]}$ Hiç şüphe yok ki, böyle bir patoloji ortamında (ki zaman zaman bu ortama enfeksiyon da eşlik edebilir) ortopedik cerrah tedavinin temel aşamalarını sağlama konusunda ısrarcı davranmalıdır. Bu aşamalar özetle; atrofik kaynamamanın geliştiği eski kırık hattında biyomekanik açıdan yeterli stabilitenin sağlanması, kanlanmanın iyi olduğu noktaya kadar nekrotik kemik debridmanı ve dekortikasyon, oluşan kemik defektinin telafisi, varsa enfeksiyonun medikal ve cerrahi yöntemler ile eradikasyonu ve greftleme olarak sıralanabilir. ${ }^{[2]}$ Kaynamama sahasındaki ana kemik fragmanları arasında biyolojik stabilitenin sağlanmasında makaslama, rotasyonel ve distrakte edici kuvvetleri en aza indirecek basitten komplekse doğru uzanan birden çok internal (plak-vida, intramedüller çivi), eksternal (Ilizarov eksternal fiksatör, hibrid sirküler fiksatör uygulamaları, bilgisayar destekli uzaysal fiksatör uygulamaları) ya da kombine fiksasyon yöntemleri mevcuttur. Uygulanacak fiksasyon yöntemine; kaynamama olgusundaki kısalık, deformite, defekt durumu ve enfeksiyon varlığı gibi parametrelere bakılarak karar verilmelidir. Atrofik kaynamamaya eşlik eden enfeksiyonun eradikasyonunda ise konvansiyonel, aktif, pulse elektromanyetik alan, antibiyotikli polimetilmetakrilat zincirleri ya da llizarov eksternal fiksatör yöntemlerinden yararlanılabilir. ${ }^{[1]}$

Teknolojik gelişmelere paralel olarak yıllar içerisinde farklılaşarak kullanımı kolaylaşan ve kırık stabilitesine ek katkılar sağlayan fiksasyon yöntemlerinin çoğalmasına ve enfeksiyon eradikasyonuna yardımcı olan medikal ve cerrahi yöntemlerin çeşitliliğine rağmen, atrofik kaynamamanın tedavisinin bu iki basamağının ana fikrinde temel olarak bir değişiklik yaşanmamış ve "stabiliteyi sağla, enfeksiyonu eradike et, kanlanmayı arttır ve defekti gider" konsepti ortopedi dünyası tarafından kabul görmüştür.

Tedavinin en önemli basamaklarından bir diğeri ise biyolojik stimülasyonun sağlanmasında gerekli olan kaynamama sahasının greftlenmesidir. ${ }^{[3-6]}$ Atrofik kaynamama tedavisinde tercih edilmesi gereken greft tipinin tedavinin başarısında doğrudan etkisi olduğuna şüphe yoktur. Benzer bir biyolojik stimülasyon, ideal mekanik ortamın sağlanması (mekanobiyoloji konsepti) ile de sağlanabilir. ${ }^{[7-10]}$ Mekanik stimülasyon, osteoblastların çoğalmasını ve farklılaşmasını stimüle ederek kemik biyolojisini hücresel seviyede doğrudan etkiler. ${ }^{[7,10]}$ Neden olduğu mekanik strese yanıt olarak oluşan piazoelektrik yüklerin kaynama sahasındaki remodelasyona da yararı vardır. ${ }^{[10,11]}$ Konu ile ilgili çalışmalarda, atrofik kaynamama sahasında canlı mezenkimal kök hücrelerin bulunduğu ve bu hücrelerin uygun ortam sağlandığında reaktive edilebileceği gösterilmiştir. ${ }^{[12,13]}$ Tibial ve humeral atrofik kaynamama olgularında llizarov eksternal fiksatör ile doğru mekanobiyolojik ortam sağlandığında, greftlemeye ihtiyaç duymadan kaynamanın elde edilebildiğini gösteren çalışmalar dikkat çekicidir. ${ }^{[14,15]}$ Benzer şekilde, periosteal kılıfın başarılı bir şekilde korunması, kemik uçların tazelenmesi, iyi kemik temas alanının sağlanması ve LCDCP plak ile dengeli bir fiksasyonun sağlanması sonucunda klavikula atrofik kaynamamasının otojen kemik grefti kullanımına gerek kalmadan başarılı bir şekilde tedavi edildiğinin anlatıldığı çalışma, mekanobiyolojik ortamın ne kadar önemli olduğunu göstermektedir.[16]

\section{ATROFIK KAYNAMAMADA GREFTLEME}

Vaskülaritenin oldukça kötü ve hücresel iyileşme mekanizmalarının oldukça zayıf olduğu atrofik 
kaynamamanın tedavisinde tercih edilecek greftin, biyolojik potansiyeli yüksek, hücresel döngüsünün hızlı ve osteojenik kapasitesinin fazla olması, greftlemenin vazgeçilmez kriterleridir. ${ }^{[1]}$ Kaynamama sahasındaki defektin kapatılmasını ana hedef olarak belirleyerek bu sahayı doldurmak amacıyla osteokondüktif özelliği ön planda olan ve hücresel kapasitesi düşük olan bir greftin tercih edilmesinin, başarısız sonuçları beraberinde getireceği aşikardır. Bu sebeplerden dolayı, neden olduğu donör sahası morbiditesi ve temin edilebilen greft miktarının sınırlı olmasına karşın, otojen kanselöz greftler, greftleme materyalleri içerisinde "altın standart" olan konumunu halen korumaktadır. $[1,17,18]$ Osteogenezisin birincil amaç olduğu durumlarda osteokondüktif (matriks içeriği) ve osteoindüktif (protein içeriği) özellikleri ile içerdiği osteoprogenitör hücreler sayesinde otojen kanselöz greft, yapısal olmayan greftler içerisinde en ideal olanıdır. ${ }^{[1,2,19-21]}$ Mezenkimal kök hücreden zengin olan otojen kemik iliği aspiratı kullanımı ise oldukça güncel bir konu olup, atrofik kaynamama tedavisinde son zamanlarda günlük pratik içerisinde yer almaya başlamış durumdadır. ${ }^{[5,14,21]}$

Allojen greftler ise kanselöz, kortikal ya da demineralize kemik matriksi (DKM) formunda bulunur. ${ }^{[21]}$ Allojen greftlerin osteojenik özelliklerinin taze otojen greftlere kıyasla daha düşük düzeyde olduğu, klinik ve deneysel çalışmalarla gösterilmiştir. ${ }^{[1]}$ Bu nedenle, allojen greftlerin atrofik kaynamamada rolü ancak ve ancak otojen kemik greftinin miktar olarak yetersiz kaldığı durumlar ile sınırlı olmalıdır. Atrofik kaynamama tedavisinde, otojen ve allojen greftler birbirileri ile karıştırılarak da kullanılabilir. Bu tarz bir kombinasyon tercihinde, seçilecek allojen greftin hem osteoindüktif hem de osteokondüktif özelliğe sahip olmasına özen göstermek mantıklı bir tercih olacaktır. Her iki özelliğe sahip en önemli allogreft DKM'dir. ${ }^{[22]}$ Uygun fiksasyon ile birlikte greftlemenin sadece DKM ile uygulandığı humerus atrofik kaynamama olgularında kaynamanın başarılı bir şekilde elde edilebildiği de belirtilmektedir. ${ }^{[23]}$ DKM uygulamasının dezavantajı yüksek maliyete sahip olmasıdır. DKM maliyeti 15 $\mathrm{ml}$ boyutundaki allojen kanselöz cips greftin yaklaşık beş katı daha fazladır. ${ }^{[6]}$

Yapısal greft ihtiyacı olduğunda, fibula dışındaki otojen kortikal greftler neden oldukları donör saha morbidite nedeniyle daha az sıklıkla kullanılmaktadır. Taze donmuş veya kuru dondurulmuş (liyofilize) allojen kortikal greftler ise sağladıkları yapısal destek açısından kuvvetli olmalarına rağmen osteojenik özellikleri oldukça kısıtlıdır ve tek başlarına kullanımlarının atrofik kaynamama durumlarındaki etkinliği yetersizdir.

Uzun kemiklerin masif defektli kaynamama durumlarında tek ya da ikili onlay otojen kemik greftleme ve masif kaydırma yöntemleri hem fiksasyon hem de osteogenezisin sağlanmasında oldukça uzun yıllardır kullanılan, etkili olmasına rağmen morbiditesi nedeniyle eski yıllarda olduğu kadar sık tercih edilmeyen greftleme yöntemleridir. ${ }^{[1]}$ Eski yıllarda, özellikle tibianın proksimal ya da distal dörtte birlik kesiminde yer alan avasküler kaynamama durumlarında sıklıkla tercih edilen yöntem, günümüzde nadiren tercih edilmektedir.

Vaskülarize olmayan tüm fibula otojen grefti $5 \mathrm{~cm}$ 'in altındaki defektli kaynamama alanlarının tedavisinde başarılı bir şekilde kullanılabilir. Tübüler yapısı ve boyutları nedeniyle özellikle radius, ulna ve humerusun defektli kaynamamalarındaki kullanımları daha güvenlidir. Çocuk yaş grubunda tibial defektlerin tedavisinde de tercih edilebilir.

Beş cm'nin üzerindeki defektli kaynamama durumunda biyolojik iyileşmenin önünü açmak için tercih edilmesi gereken yöntemler, ya serbest vaskülarize kemik ile greftleme ya da distraksiyon osteogenezis yöntemleridir. ${ }^{[1,24]}$ Vaskülarize kemik grefti temini için fibula, skapula ya da femur mediyal suprakondiller alandaki kortikoperiosteal bölge tercih edilebilir. ${ }^{[24]}$ Kemik transportu uygulanan yöntemlerde de, transporte edilen kemik fragmanı defektin öteki ucuna tamamen yaslandığında karşılaşma sahasının otojen kanselöz kemik ile greftlenmesi sık kullanılan bir yöntemdir. Hem hasta hem de tedavi eden ortopedist açısından zahmetli ve uzun süren tedaviler olmasına rağmen, her iki yöntem defektli atrofik kaynamamalardaki patolojik süreçlerin her birinde (defekt varlığı, vaskülarite problemi ve stabilite temini) sorunu doğrudan çözmeyi hedefleyen metodlardır. Bu yöntemleri tercih etmek isteyen bir ortopedistin, mikrocerrahi ya da eksternal fiksatör kullanımı ve kemik transportu uygulama konularına hâkim olması gerekmektedir.

Otojen kemik grefti donörleri ve donör sahaları arasında gen ekspresyon seviyeleri, mezenkimal kök hücre ve kemik morfojenik protein konsantrasyonları açısından doğal varyasyonların olması, otojen kemik greftlerinin iyileştirme potansiyellerinde kişisel farklılıklara yol açmaktadır. ${ }^{[25-27]} \mathrm{Bu}$ farklılıklar, kırık iyileşmesini kolaylaştıracak sentetik greftlerin araştırılmasına neden olmuştur. Bu sentetik greftlerden biri de rekombinant insan kökenli kemik morfojenik proteindir (riKMP). riKMP'nin uzun kemik kırıklarının iyileşme hızını arttırdığı ve kaynamama durumlarında güvenle kullanılabileceği gösterilmiştir. ${ }^{[28,29]}$ Literatürde riKMP'nin atrofik kaynamama olgularındaki etkinliği ile ilgili birbiriyle çelişkili sonuçlar yer almaktadır. riKMP ile kombine edilmiş allojen kortikal kemik greftlerinin femur kaynamamalarında tedavisinde başarılı sonuç verdiği bildiren ${ }^{[1]}$ ve uzun kemiklerin atrofik kaynamama olgularının tedavisinde otojen kemik grefti ve riKMP-7'nin birlikte 
kullanımının etkinliğini raporlayan ${ }^{[30]}$ geriye dönük çaIsşmaların aksine otojen kemik greftine riKMP-2 ilavesinin uzun kemik kaynamamalarının iyileşme miktarına ve süresine umulan sinerjistik etkiyi vermediğini ortaya koyan ileriye dönük çalışma da mevcuttur. ${ }^{[6]}$ riKMP kullanımının belirgin bir katkı sağlamadığını belirten başka çalışmalar da mevcuttur. ${ }^{[31-34]}$ Lehte ve aleyhte farklı klinik sonuçların yanı sıra riKMP-2'nin yüksek maliyeti de (2014 yılında ABD'deki $5 \mathrm{ml}$ boyutundaki formunun maliyeti $\$ 3500$ civarındadır ${ }^{[6]}$ kullanımını, özellikle de ülkemizde güçleştirmektedir. Atrofik kaynamama tedavisinde kaynamaya olan etkisi ile ilgili olmasa da, yakın dönemde lomber spinal artrodez sağlanması amacıyla yüksek doz (40 mg) riKMP-2 kullanımının yeni kanser oluşma riskini yükselttiğine dair verinin yayımlanması ise riKMP-2'nin güvenilirliği konusunda şüphe uyandırmaktadır. ${ }^{35]}$

Sentetik seramik greftlerin (kalsiyum sülfat, kalsiyum fosfat, trikalsiyum fosfat, hidroksiapatit ve kompozit biyoseramikler) ise osteokondüktif özellikleri ön plandadır ve bunlar donör saha morbiditesine neden olmaz ${ }^{[21]}$ ve oldukça kırılgan bir yapıya sahiptir. Atrofik kaynamama tedavisinde birincil önceliğe sahip olmayan bu tipteki greftlerin kemik morfojenik protein ya da otojen kemik iliği gibi bir başka osteoindüktif karakterde protein ile kombine edilmesi, greftin etkinliğinin artmasına yardımcı olur.

Heterojen greft materyallerinin (insan kaynaklı olmayan, xenograft) atrofik kaynamama tedavisinde tanımlanmış bir yeri yoktur. Biyolojik aktiviteden yoksun olan bu tür greftler, atrofik kaynamama tedavisinde kullanılmamalıdır.

\section{KAYNAKLAR}

1. Cleveland KB. Delayed union and nonunion of fractures. In: Canale ST, Beaty JH, editors. Campbell's Operative Orthopaedics, 12th edition. Philadelphia: Elsevier Mosby; 2013. pp.2981-3016.

2. Reisoğlu A, Ağuş H. Kaynamamalarda (psödoartroz) tanı ve tedavi. TOTBID Derg 2008;7:72-80.

3. Jones $C B$, Mayo KA. Nonunion treatment: iliac crest bone graft techniques. J Orthop Trauma 2005;19(10 Suppl):S11-3.

4. Wu CC, Chen WJ. A revised protocol for more clearly classifying a nonunion. J Orthop Surg (Hong Kong) 2000;8:45-52. Crossref

5. Hernigou P, Poignard A, Beaujean F, Rouard H. Percutaneous autologous bone-marrow grafting for nonunions. Influence of the number and concentration of progenitor cells. J Bone Joint Surg Am 2005;87(7):1430-7. Crossref

6. Takemoto R, Forman J, Taormina DP, Egol KA. No advantage to rhBMP-2 in addition to autogenous graft for fracture nonunion. Orthopedics 2014;37(6):e525-30. Crossref

7. Bhandari M, Schemitsch E. Clinical advances in the treatment of fracture nonunion: the response to mechanical stimulation. Curr Opin Orthop 2000;11:372-7.
8. Carter DR, Beaupré GS, Giori NJ, Helms JA. Mechanobiology of skeletal regeneration. Clin Orthop Relat Res 1998;(355 Suppl):S41-55.

9. Kloen P, Doty SB, Gordon E, Rubel IF, Goumans MJ, Helfet DL. Expression and activation of the BMP-signaling components in human fracture nonunions. J Bone Joint Surg Am 2002;84-A(11):1909-18.

10. Chen JC, Carter DR. Important concepts of mechanical regulation of bone formation and growth. Curr Opin Orthop 2005; 16:338-45.

11. Webb JCJ, Tricker J. Bone Biology a review of fracture healing. Curr Orthopaed 2000;14:457-63.

12. Sun $D$, Yuan $D$, Zhang $X$. A new hypothesis on the mechanism of atrophic non-union. Med Hypotheses 2011;77(1):69-70. Crossref

13. Ismail HD, Phedy P, Kholinne E, Kusnadi Y, Sandhow L, Merlina M. Existence of mesenchymal stem cells in sites of atrophic nonunion. Bone Joint Res 2013;2(6):112-5. Crossref

14. Ferreira N, Marais LC, Aldous C. Mechanobiology in the management of mobile atrophic and oligotrophic tibial nonunions. J Orthop 2015;12(Suppl 2):S182-7. Crossref

15. Tomić S, Bumbasirević M, Lesić A, Mitković M, Atkinson HD. llizarov frame fixation without bone graft for atrophic humeral shaft nonunion:28 patients with a minimum 2-year follow-up. J Orthop Trauma 2007;21(8):549-56. Crossref

16. Huang HK, Chiang CC, Su YP, Feng CK, Chiu FY, Liu CL, Chen $\mathrm{TH}$. Role of autologous bone graft in the surgical treatment of atrophic nonunion of midshaft clavicular fractures. Orthopedics 2012;35(2):e197-201. Crossref

17. Schmidmaier G, Schwabe P, Wildemann B, Haas NP. Use of bone morphogenetic proteins for treatment of non-unions and future perspectives. Injury 2007;38 Suppl 4:S35-41.

18. Sen MK, Miclau T. Autologous iliac crest bone graft: should it still be the gold standard for treating nonunions? Injury 2007;38 Suppl 1:S75-80. Crossref

19. Bauer TW, Muschler GF. Bone graft materials. An overview of the basic science. Clin Orthop Relat Res 2000;(371):10-27.

20. Samartzis D, Shen FH, Goldberg EJ, An HS. Is autograft the gold standard in achieving radiographic fusion in one-level anterior cervical discectomy and fusion with rigid anterior plate fixation? Spine (Phila Pa 1976) 2005;30(15):1756-61.

21. Fillingham $Y$, Jacobs $J$. Bone grafts and their substitutes. Bone Joint J 2016;98-B(1 Suppl A):6-9. Crossref

22. Crenshaw $\mathrm{AH}$ Jr. Surgical techniques and approaches. In: Canale ST, Beaty JH, editors. Campbell's Operative Orthopaedics, 12th edition. Philadelphia: Elsevier Mosby; 2013. pp.2-126.

23. Hierholzer C, Sama D, Toro JB, Peterson M, Helfet DL. Plate fixation of ununited humeral shaft fractures: effect of type of bone graft on healing. J Bone Joint Surg Am 2006;88(7):14427. Crossref

24. Muramatsu K, Doi K, Ihara K, Shigetomi M, Kawai S. Recalcitrant posttraumatic nonunion of the humerus: 23 patients reconstructed with vascularized bone graft. Acta Orthop Scand 2003;74(1):95-7. Crossref

25. D'Ippolito G, Schiller PC, Ricordi C, Roos BA, Howard GA. Age-related osteogenic potential of mesenchymal stromal stem cells from human vertebral bone marrow. J Bone Miner Res 1999;14(7):1115-22. Crossref

26. Takemoto RC, Fajardo M, Kirsch T, Egol KA. Quantitative assessment of the bone morphogenetic protein expression from alternate bone graft harvesting sites. J Orthop Trauma 2010;24(9):564-6. Crossref 
27. Stolzing A, Jones E, McGonagle D, Scutt A. Age-related changes in human bone marrow-derived mesenchymal stem cells: consequences for cell therapies. Mech Ageing Dev 2008;129(3):163-73. Crossref

28. Govender S, Csimma C, Genant HK, Valentin-Opran A, Amit $\mathrm{Y}$, Arbel R, Aro H, Atar D, Bishay M, Börner MG, Chiron P, Choong P, Cinats J, Courtenay B, Feibel R, Geulette B, Gravel C, Haas N, Raschke M, Hammacher E, van der Velde D, Hardy P, Holt M, Josten C, Ketterl RL, Lindeque B, Lob G, Mathevon H, McCoy G, Marsh D, Miller R, Munting E, Oevre S, Nordsletten L, Patel A, Pohl A, Rennie W, Reynders P, Rommens PM, Rondia J, Rossouw WC, Daneel PJ, Ruff S, Rüter A, Santavirta S, Schildhauer TA, Gekle C, Schnettler R, Segal D, Seiler H, Snowdowne RB, Stapert J, Taglang G, Verdonk R, Vogels L, Weckbach A, Wentzensen A, Wisniewski T; BMP-2 Evaluation in Surgery for Tibial Trauma (BESTT) Study Group. Recombinant human bone morphogenetic protein-2 for treatment of open tibial fractures: a prospective, controlled, randomized study of four hundred and fifty patients. J Bone Joint Surg Am 2002;84-A(12):2123-34.

29. Bong MR, Capla EL, Egol KA, Sorkin AT, Distefano M, Buckle $\mathrm{R}$, Chandler RW, Koval KJ. Osteogenic protein-1 (bone morphogenic protein-7) combined with various adjuncts in the treatment of humeral diaphyseal nonunions. Bull Hosp Jt Dis $2005 ; 63(1-2): 20-3$.
30. Giannoudis PV, Kanakaris NK, Dimitriou R, Gill I, Kolimarala $\mathrm{V}$, Montgomery RJ. The synergistic effect of autograft and BMP-7 in the treatment of atrophic nonunions. Clin Orthop Relat Res 2009;467(12):3239-48. Crossref

31. Tressler MA, Richards JE, Sofianos D, Comrie FK, Kregor PJ, Obremskey WT. Bone morphogenetic protein-2 compared to autologous iliac crest bone graft in the treatment of long bone nonunion. Orthopedics 2011;34(12):e877-84. Crossref

32. Carragee EJ, Hurwitz EL, Weiner BK. A critical review of recombinant human bone morphogenetic protein-2 trials in spinal surgery: emerging safety concerns and lessons learned. Spine J 2011;11(6):471-91. Crossref

33. Chutkan NB. The effect of recombinant human bone morphogenetic protein-2 in single-level posterior lumbar interbody arthrodesis. Orthopedics 2013;36(9):712-3. Crossref

34. Michielsen J, Sys J, Rigaux A, Bertrand C. The effect of recombinant human bone morphogenetic protein- 2 in singlelevel posterior lumbar interbody arthrodesis. J Bone Joint Surg Am 2013;95(10):873-80. Crossref

35. Carragee EJ, Chu G, Rohatgi R, Hurwitz EL, Weiner BK, Yoon ST, Comer G, Kopjar B. Cancer risk after use of recombinant bone morphogenetic protein-2 for spinal arthrodesis. J Bone Joint Surg Am 2013;95(17):1537-45. Crossref 